\title{
CONTRIBUTION TO THE HERPETOFAUNA OF SERBIA - DISTRIBUTION OF REPTILES IN KOSOVO AND METOHIJA PROVINCE
}

\author{
LJILJANA TOMOVIĆ ${ }^{*}$, MAGDALENA TIMOTIJEVIĆ ${ }^{2}$ RASTKO AJTIĆ IMRE $^{3}$ IMRO \\ KRIZMANIĆ ${ }^{1}$, NENAD LABUS ${ }^{2}$
}

${ }^{1}$ Institute of Zoology, Faculty of Biology, University of Belgrade, Belgrade, Serbia

${ }^{2}$ Faculty of Science and Mathematics, University of Priština, Kosovska Mitrovica, Serbia

${ }^{3}$ Institute for Nature Conservation of Serbia, Belgrade, Serbia

\begin{abstract}
Kosovo and Metohija have already been recognized as regions with the highest diversity of reptiles in Serbia, where $92 \%$ ( 22 of 24 ) of existing reptile species can be found (Tomović et al., 2015a). First comprehensive contribution to herpetofauna of Kosovo and Metohija was provided by late Professor Gojko Pasuljević. In this study we present a complete dataset of distribution records for 13 most common reptile species in Kosovo and Metohija, including published and new distribution data compiled, and provide standardized 10 x $10 \mathrm{~km}$ UTM maps for these data. Results of this study include 1013 distribution records (278 new and 735 published data) for the following reptiles: Testudo hermanni, Ablepharus kitaibelii, Anguis fragilis, Lacerta agilis, Lacerta viridis, Podarcis muralis, Podarcis tauricus, Coronella austriaca, Dolichophis caspius, Natrix natrix, Natrix tessellata, Zamenis longissimus and Vipera ammodytes. The most widely distributed species, which occupy more than 50 UTM $10 \times 10 \mathrm{~km}$ squares are: Podarcis muralis and Vipera ammodytes. Species with limited distribution which occupy less than 20 UTM 10 x $10 \mathrm{~km}$ are: Dolichophis caspius and Lacerta agilis. The largest numbers of new or confirmed literature data are recorded for: Anguis fragilis, Testudo hermanni and Vipera ammodytes. Having in mind that after 50 years, this is the first comprehensive study of the distribution of reptiles in Kosovo and Metohija exclusively, the presented faunistic data are far from being complete. Further systematic studies should provide a more complete insight into the distribution of herpetofauna of this province of Serbia.
\end{abstract}

Keywords: Herpetofauna, Faunistics, Serbia, Kosovo and Metohija.

\section{INTRODUCTION}

The first important step preceding the studies of systematics, ecology and biogeography is the comprehensive knowledge of biodiversity of a certain region. Therefore, systematic faunistic studies are of increasing significance, especially in the regions or countries with incomplete species distribution data (Margules et al., 2002; Jelić et al., 2013; Tomović et al., 2014). Detailed distribution data are essential for identification of biodiversity "hotspots" i.e. areas with exceptional species assemblages, high levels of endemicity and/or areas under significant threats (Gaston et al., 2002).

Concerning the herpetofauna, the Balkan Peninsula is recognized as one of the richest biodiversity hotspots in Europe (Džukić \& Kalezić, 2004). Being situated in the central part of the Balkans, Serbia is a very important territory for diversity of reptiles, due to the occurrence of various biogeographical phenomena: presence of the Balkan endemic species and relicts, different faunal elements, marginality of certain species' ranges and presence of peripheral populations, as well as range fragmentation (Džukić, 1995; Džukić \& Kalezić, 2004).

\footnotetext{
* Corresponding author: lili@bio.bg.ac.rs BIOLOGY
}

Province of Kosovo and Metohija has already been identified as one of the regions with the highest reptile's diversity in Serbia, with 22 species recorded (Tomović et al., 2015a). First comprehensive contribution to herpetofauna of Kosovo and Metohija was given by Pasuljević (1968). In the following decades, faunistic papers were primarily focused on several rare (or uncommon) species with peripheral or disjunct occurrence within the territory of ex-Yugoslavia or Serbia: Algyroides nigropunctatus (Džukić, 1970; Džukić \& Pasuljević, 1979), Darevskia praticola (Džukić, 1974; Pasuljević \& Džukić, 1979), Cyrtodactylus kotschyi (Ajtić \& Tomović, 2001).

The most recent publication of complete herpetofauna of Serbia (including Kosovo and Metohija) presented only broad overview of confirmed or potential distribution of reptile species, but without precise distribution records (Tomović et al., 2014). Several species or group-oriented papers for the territory of Serbia provided complete distribution summary and filled up the gap concerning distribution of reptiles in Kosovo and Metohija: Emys orbicularis (Krizmanić et al., 2015; Golubović et al., 2017), Testudo hermanni (Ljubisavljević et al., 2014), Testudo graeca (Tomović et al., 2004; Ralev et al., 2013), Ablepharus kitaibelii (Ljubisavljević et al., 2015), Lacertids (Urošević et al., 2015), Colubrids (Tomović et al., 2015b) and Vipers (Jelić et al., 2013). However, data concerning the distribution of the most 
common, well-known and generally widespread species (e. g. Lacerta agilis, Lacerta viridis, Podarcis muralis, Natrix natrix, Natrix tessellata, Coronella austriaca and Zamenis longissimus) were relatively poor and scattered.

Therefore, with this study we aim to: (i) publish a complete dataset of distribution records of 13 most common reptile species in Kosovo and Metohija, summarizing already published and new distribution data, and (ii) provide standardized $10 \times 10 \mathrm{~km}$ UTM maps of the summarized data.

\section{MATERIAL AND METHODS}

In this study, we presented a large dataset (1013 occurrence records) of distribution of the most common species of herpetofauna in Kosovo and Metohija.

This study is based on the species' occurrence records from authors' field observations (field data) which were kindly donated by our colleagues (see Acknowledgements). The species were identified using standard herpetological literature (Arnold \& Ovenden, 2002), by visual inspection of specimens from the photographs, or directly in the field. Regarding taxonomy and current nomenclature, we followed Jablonski et al. (2016), Sillero et al. (2014) and Uetz et al. (2017). Due to several objective reasons, the entire territory of Kosovo and Metohija (Figure 1) was not covered by faunistic research. Our dataset is still incomplete; the lack of data from certain areas does not necessarily imply the absence of species. In addition to new (field) records, we used 735 published records from the available literature.

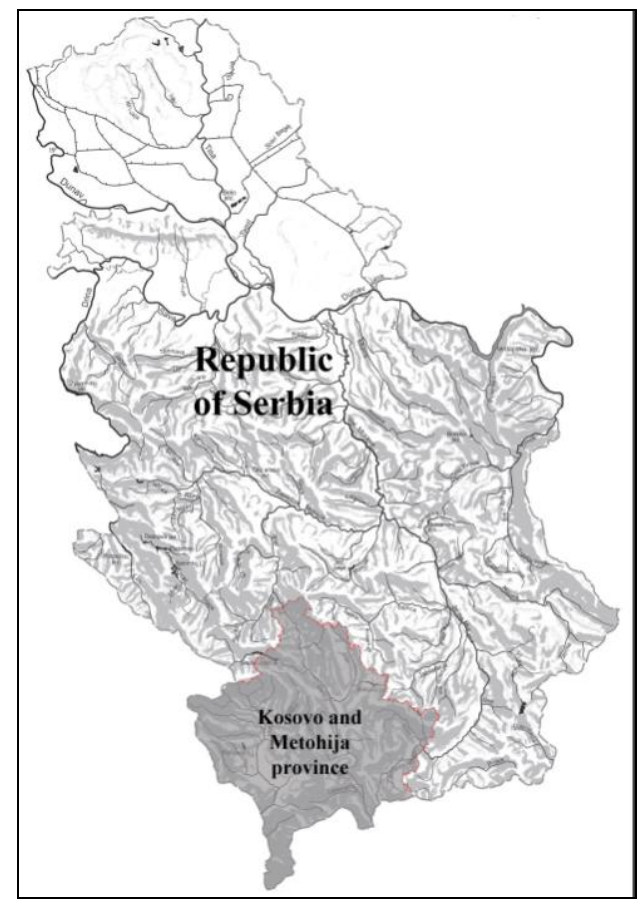

Figure 1. Map of Republic of Serbia with study area - Kosovo and Metohija province (grey).
The data were classified as: (i) new field data (red-white dots), (ii) literature data (red-black dots) and (iii) existing data confirmed by field work (red dots). All records were mapped in the $10 \times 10 \mathrm{~km}$ UTM (Universal Transverse Mercator) grid.

We applied the threshold of occurrence in classifying the abundancy of the species: (i) most widely distributed species (more than 50 UTM $10 \times 10 \mathrm{~km}$ squares), (ii) quite widely distributed species (43 - 47 UTM $10 \times 10 \mathrm{~km}$ squares), (iii) relatively common species ( 27 - 34 UTM $10 \times 10 \mathrm{~km}$ squares), (iv) species with limited distribution (less than 20 UTM $10 \times 10$ km squares).

\section{RESULTS}

Results of this study included 1013 distribution records (278 new and 735 published data) for 13 most common reptiles in Kosovo and Metohija province: Testudo hermanni, Ablepharus kitaibelii, Anguis fragilis, Lacerta agilis, Lacerta viridis, Podarcis muralis, P. tauricus, Coronella austriaca, Dolichophis caspius, Natrix natrix, N. tessellata, Zamenis longissimus and Vipera ammodytes. We excluded other nine reptile species which inhabit this part of Serbia (Tomović et al., 2015a), due to lack of new faunistic data. In Figures 2-5, detailed distribution records of 13 reptile species in Kosovo and Metohija province are provided.

For each species, new records in Kosovo and Metohija (with broad locations, exact localities, toponyms, UTM and names of persons who provided data) are given in Appendix 1. Data from the literature (with broad locations, exact localities, toponyms, UTM and literature sources) are presented in Appendix 2.

According to our dataset, the most widely distributed species in the entire territory of Kosovo and Metohija are: the wall lizard (Podarcis muralis - 55) and the nose-horned viper (Vipera ammodytes - 53). Four reptile species are quite widely distributed: the grass snake (Natrix natrix - 47), the green lizard (Lacerta viridis - 47), the Hermann's tortoise (Testudo hermanni - 44) and the Aesculapian snake (Zamenis longissimus - 43). Relatively common species are: the Balkan wall lizard (Podarcis tauricus - 34), the dice snake (Natrix tessellata - 31), the smooth snake (Coronella austriaca - 31), the snake-eyed skink (Ablepharus kitaibelii - 29) and the slow-worm (Anguis fragilis - 27). Species with limited distribution in Kosovo and Metohija are: the Caspian whip-snake (Dolichophis caspius - 15) and the sand lizard (Lacerta agilis - 13) (Figures 2-5). The largest numbers of new or confirmed literature data are recorded for the following species: Anguis fragilis (19 new and 6 confirmed literature data), Testudo hermanni (18 new and 11 confirmed literature data) and Vipera ammodytes ( 8 new and 32 confirmed literature data). 

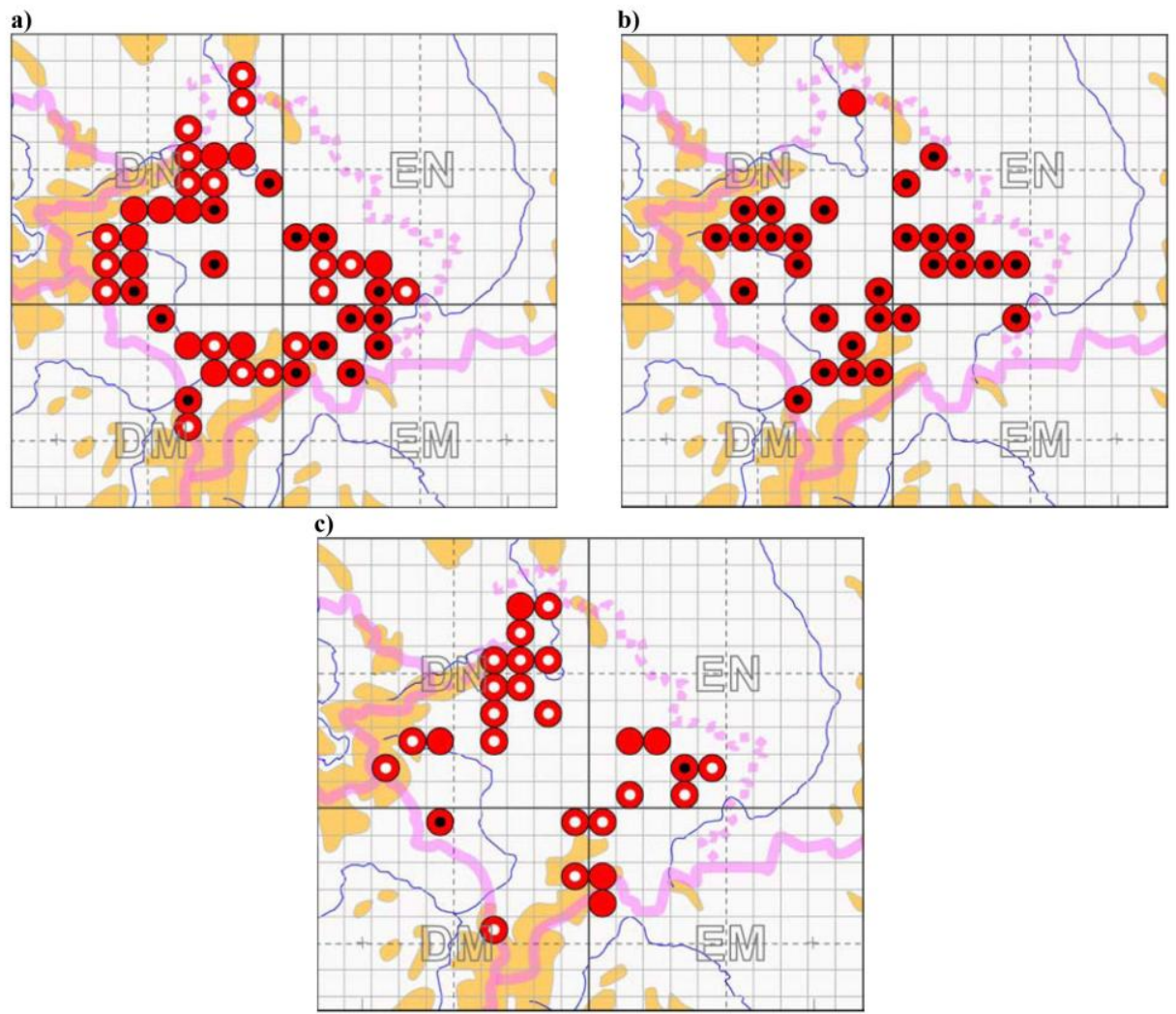

Figure 2. Records of a) Testudo hermanni, b) Ablepharus kitaibelii, c) Anguis fragilis in Kosovo and Metohija (National Grid UTM 10 x 10 km). Red-white dots - new records, Red-black dots - literature c records, Red dots - literature + new records.
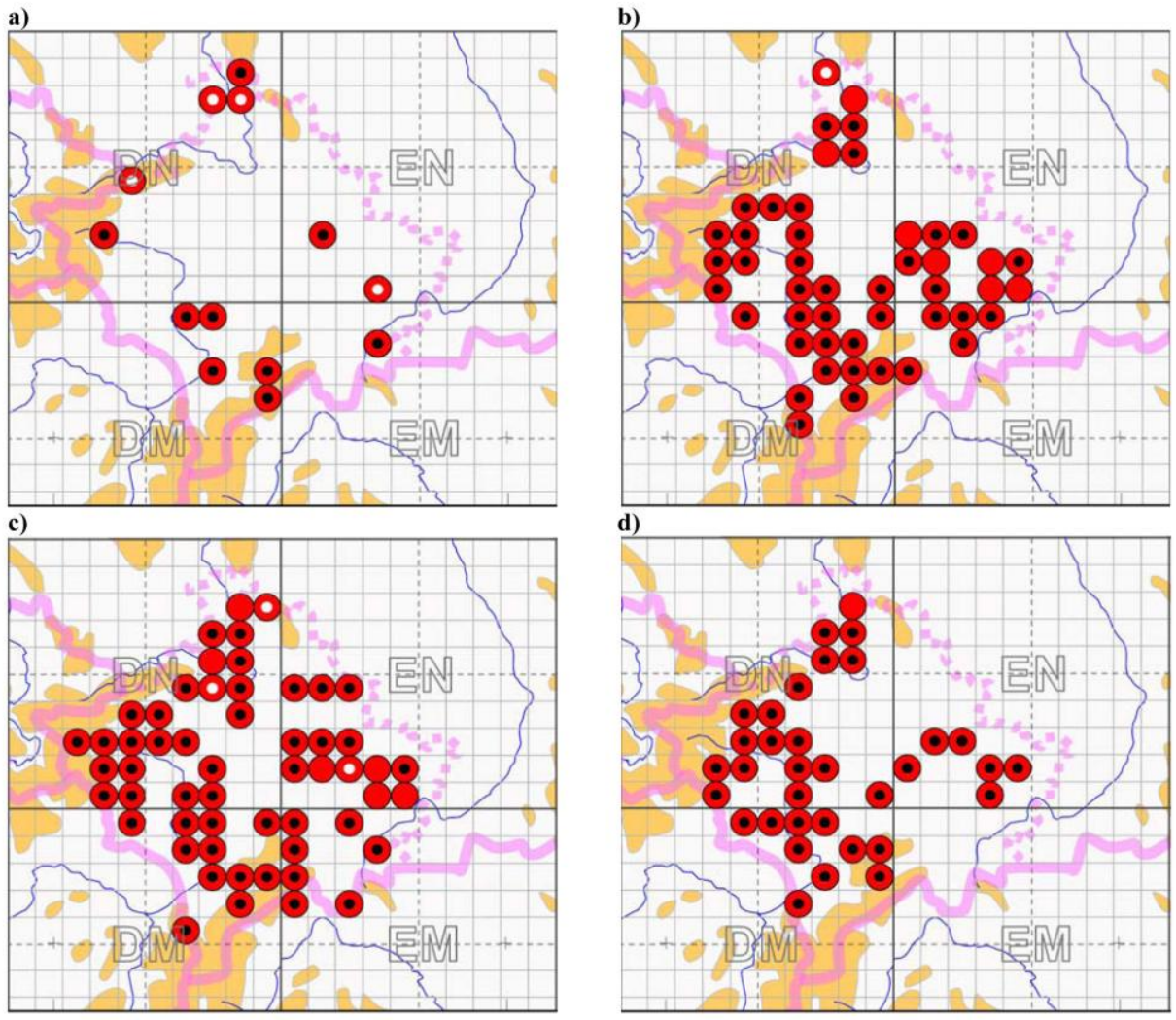

Figure 3. Records of a) Lacerta agilis, b) Lacerta viridis, c) Podarcis muralis, d) Podarcis tauricus in Kosovo and Metohija (National Grid UTM 10 x $10 \mathrm{~km}$ ). Red-white dots - new records, Red-black dots - literature records, Red dots - literature + new records. 


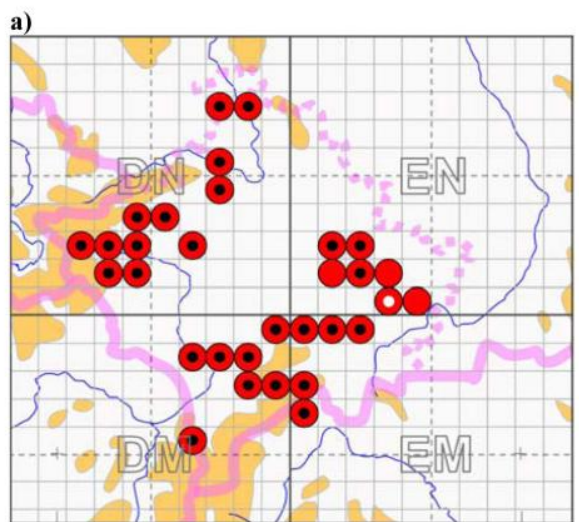

c)

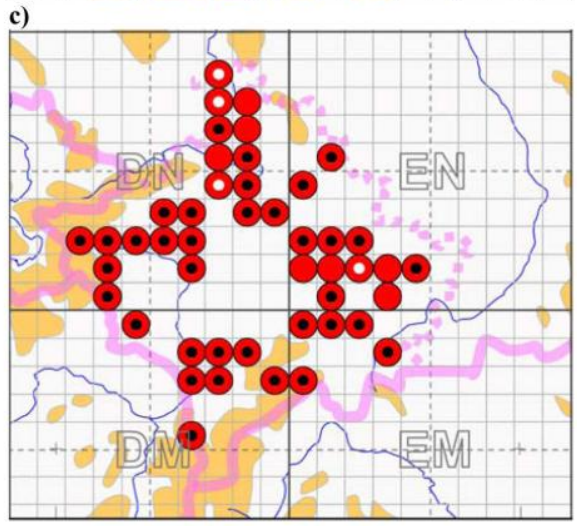

b)

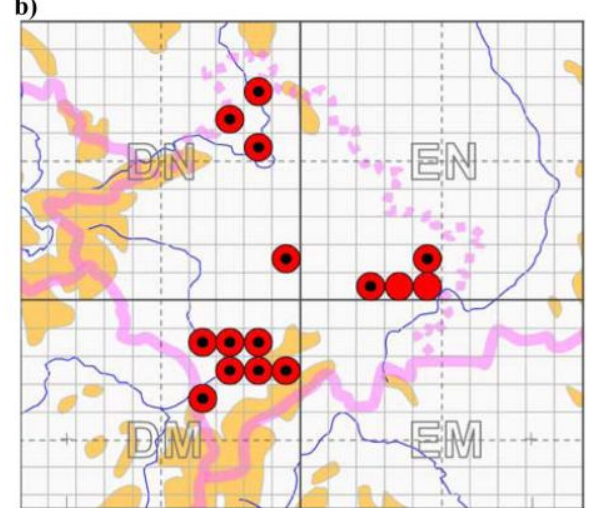

d)

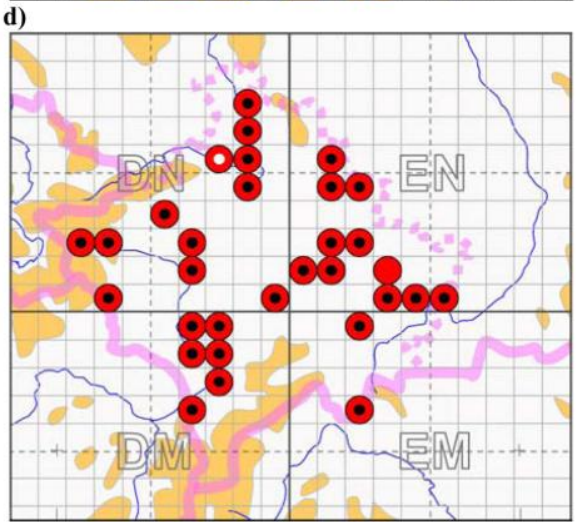

Figure 4. Records of a) Coronella austriaca, b) Dolichophis caspius, c) Natrix natrix, d) Natrix tessellata in Kosovo and Metohija (National Grid UTM 10 × 10 km). Red-white dots - new records, Red-black dots - literature records, Red dots - literature + new records.
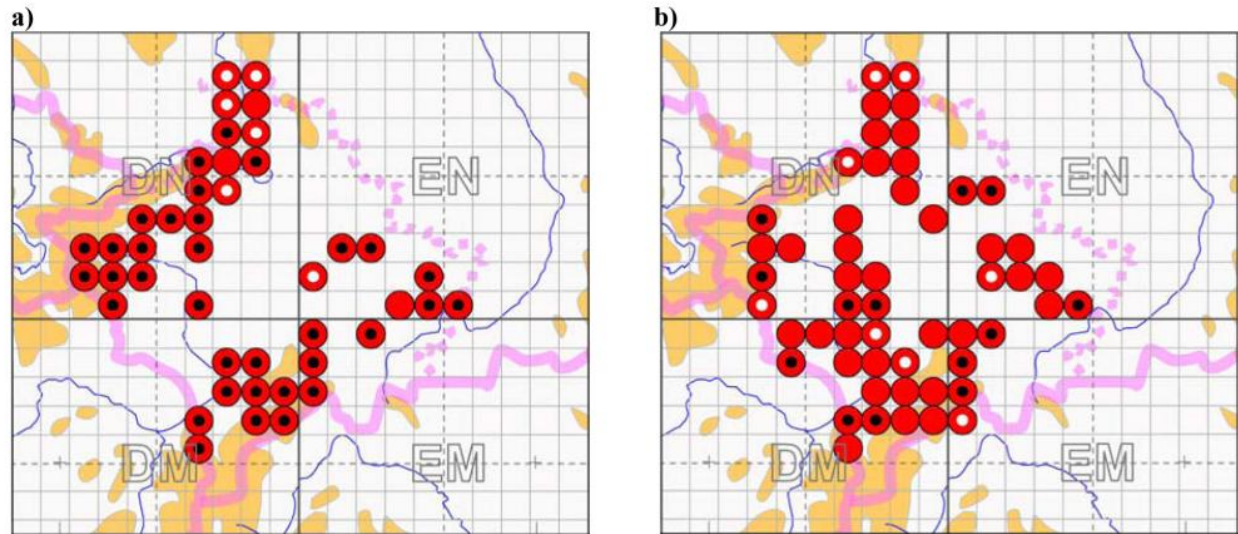

Figure 5. Records of a) Zamenis longissimus, b) Vipera ammodytes in Kosovo and Metohija (National Grid UTM $10 \mathrm{x} 10 \mathrm{~km}$ ). Redwhite dots - new records, Red-black dots - literature records, Red dots - literature + new records.

\section{DISCUSSION}

Kosovo and Metohija have already been recognized as regions with the highest diversity of reptiles in Serbia, were $92 \%$ (22 of 24) of existing reptile species can be found (Tomović et al., 2015a). The only missing species are Elaphe quatuorlineta and Platyceps najadum, which occur in southern Serbia (Pčinja river valley) (Tomović et al., 2015a).

Comparison of distribution of reptiles in Kosovo and Metohija with the entire territory of Serbia reveals a similar pattern: the most common species in Serbia are widely distributed in Kosovo and Metohija as well. All these species show uniform occurrence, determined by the presence of various adequate habitats, from lowlands to high mountains, as well as from aquatic to forest habitats. The new faunistic data expand their known distribution in Kosovo and Metohija. Presence of gaps in distribution reflects rather the lack of faunistic research in particular regions, than the actual absence of the species.

The largest number of new and literature records exist for three species which distribution in Serbia has not been published 
yet (Anguis fragilis), or which distribution included the complete territory of ex Yugoslavia: Testudo hermanni (Ljubisavljević et al., 2014) and Vipera ammodytes (Jelić et al., 2013).

According to our dataset, two reptiles show limited and, to some extent, disjunct distribution in Kosovo and Metohija: Lacerta agilis and Dolichophis caspius (Figures 3 and 4). In Serbia, Lacerta agilis inhabits areas with continental and alpine climates, and avoids moderate-continental and subMediterranean climates (Urošević et al., 2015); the same distribution pattern appears in Kosovo and Metohija. Dolichophis caspius has also a very fragmented and relatively restricted range in our country (Tomović et al., 2015b). The Caspian whip snake is associated with open steppe and foreststeppe habitats (Arnold \& Ovenden, 2002). The most probable reason for its current distribution pattern is the lack of suitable habitats caused by alterations of original steppes and foreststeppes into agricultural fields. It should be noted that small number of distribution records for these two species could also be the consequence of insufficient faunistic research.

As previously mentioned (Tomović et al., 2015b), in addition to five Colubrid species recorded in Kosovo and Metohija until now, some other taxa can be expected: Hierophis gemonensis, Malpolon insignitus, Telescopus fallax and Zamenis situla. These species reach their distribution limits in Macedonia (Sterijovski et al., 2014) or in Albania (Haxhiu, 1998), very close to the Serbian border. Thus, we suppose that the presence of the abovementioned snakes in Kosovo and Metohija could be confirmed in the future studies. Dinarolacerta montenegrina, endemic lizard of the Prokletije mountain massif, is known from a small number of locations in Montenegro and Albania (Ljubisavljević et al., 2016; Mizsei et al., 2017). Parts of the Prokletije Massif lie in the bordering areas of the western Metohija, therefore, this species could also be expected in this area as well (Urošević et al., 2015).

Having in mind that after 50 years, this is the first comprehensive study of the distribution of reptiles in Kosovo and Metohija exclusively, the faunistic data presented herein are far from being complete; As it can be seen from this study, many areas (e.g. in Metohija) are still insufficiently studied. Further systematic studies of both rare and common reptile species, should provide a more comprehensive insight into the distribution and diversity of herpetofauna of this province of Republic of Serbia.

\section{ACKNOWLEGMENTS}

We would like to thank Dr Marjan Niketić and Dr Gordana Tomović for their help with distribution maps. Many thanks to students of Biology Department, Faculty of Science and Mathematics, University of Priština who provided additional field distribution data: A. Savić, B. Aksić, M. Maksimović, M. Orlović, M. Petković and N. Todorović. Field data of late Professor Gojko Pasuljević were also included in this paper.
Research was funded by: Ministry of Education, Sciences and Technological Development (grant No. 173043) of the Republic of Serbia.

Appendix 1 and Appendix 2 are available at https://utnsjournal.pr.ac.rs

\section{REFERENCES}

Ajtić, R., \& Tomović, Lj. 2001. First record of Kotschy's gecko Cyrtodactylus kotschyi (Steindachner, 1870) (Gekkonidae, Lacertilia) in FR Yugoslavia. Archives of Biological Sciences, 53, pp. 23P-24P.

Arnold, E., \& Ovenden, D. 2002. A Filed Guide to the Reptiles and Amphibians of Britain and Europe.London: Harper Collins Publishers. $2^{\text {nd }}$ edition.

Džukić, G. 1970. Beitrag zur kenntis der verbreitung der Algyroides nigropunctatus Dumeril et Bibron in Jugoslawien. Fragmenta Balcanica, 7, pp. 149-155.

Džukić, G. 1974. Prilog herpetofauni Srbije. Glasnik Prirodnjačkog Muzeja, Series B, 29, pp. 105-110.

Džukić, G. 1995. Diverzitet vodozemaca (Amphibia) i gmizavaca (Reptilia) Jugoslavije, sa pregledom vrsta od međunarodnog značaja. In V. Stevanović \& V. Vasić Eds., Biodiverzitet Jugoslavije sa pregledom vrsta od međunarodnog značaja.Beograd: Biološki fakultet / Ecolibri. pp. 449-469.

Džukić, G., \& Kalezić, M. L. 2004. The Biodiversity of Amphibians and Reptiles in the Balkan Peninsula. In H.I. Griffiths, B. Kryštufek, \& J. M. Reed Eds., Balkan Biodiversity: Pattern and Process in the European Hotspot. Dordrecht: Springer Nature, pp. 167-192. doi:10.1007/978-14020-2854-0_10

Džukić, G., \& Pasuljević, G. 1979. O rasprostranjenju ljuskavog guštera Algyroides nigropunctatus (Dumeril et Bibron, 1839) (Reptilia, Lacertidae). Biosistematika, 5, pp. 61-70.

Gaston, K. J., Pressey, R. L., \& Margules, C. R. 2002. Persistence and vulnerability: Retaining biodiversity in the landscape and in protected areas. Journal of Biosciences, 27(4), pp. 361-384. doi:10.1007/bf02704966

Golubović, A., Grabovac, D., \& Popović, M. 2017. Actual and potential distribution of the European Pond Turtle, Emys orbicularis (L. 1758) in Serbia, with conservation implications. Acta Zoologica Bulgarica, Supplementum, 10, pp. 49-56.

Haxhiu, I. 1998. The Reptilia of Albania: Species composition, distribution, habitats. Bonner zoologische Beiträge, 48, pp. 35-57.

Jablonski, D., Jandzik, D., Mikulíček, P., Džukić, G., Ljubisavljević, K., Tzankov, N., Jelić, D., Thanou, E., Moravec, J., \& Gvoždík, V.. 2016. Contrasting evolutionary histories of the legless lizards slow worms (Anguis) shaped by the topography of the Balkan Peninsula. BMC Evolutionary Biology, 16(1).doi:10.1186/s12862-016-0669-1

Jelić, D., Ajtić, R., Sterijovski, B., Crnobrnja-Isailović, J., Lelo, S., \& Tomović, Lj. 2013. Distribution of the genus Vipera in the western and central Balkans. Herpetozoa, 25, pp. 109 132.

Krizmanić, I., Urošević, A., Simović, A., Krstić, M., Jović, D., Ajtić, R., Anđelković, M., Slijepčević, M., Đorđević, S., 
Golubović, A., Žikić, V., \& Džukić, G. 2015. Updated distribution of the European pond turtle Emys orbicularis (Linnaeus, 1758) and its conservation issues in Serbia. Arhiv za bioloske nauke, 67(3), pp. 1043-1053. doi:10.2298/abs150210067k

Ljubisavljević, K., Arribas, O., Džukić, G., \& Carranza, S. 2007. Genetic and morphological differentiation of Mosor rock lizards, Dinarolacerta mosorensis (Kolombatovic, 1886), with the description of a new species from the Prokletije Mountain Massif (Montenegro) (Squamata: Lacertidae). Zootaxa, 1613, pp. 1-22.

Ljubisavljević, K., Džukić, G., Vukov, T. D., \& Kalezić, M. L. 2014. Distribution patterns of Hermann's tortoise Testudo hermanni Gmelin, 1789, in the region of former Yugoslavia (Testudines: Testudinidae). Herpetozoa, 26, pp. 125-138.

Ljubisavljević, K., Polović, L., Vuksanović, S., \& Iković, V. 2014. A new record of the Prokletije rock lizard, Dinarolacerta montenegrina (Squamata: Lacertidae) in Montenegro. Ecologica Montenegrina, 1, pp. 201-203.

Ljubisavljević, K., Tomović, Lj., Simović, A., Krizmanić, I., Ajtić, R., Jović, D., Urošević, A., Labus, N., Đorđević, S., Golubović, A., Anđelković, M., \& Džukić, G. 2015. Distribution of the Snake-eyed skink Ablepharus kitaibelii Bibron and Bory, 1833 (Squamata: Scincidae) in Serbia. Ecologica Montenegrina, 2, pp. 247-254.

Margules, C. R., Pressey, R. L., \& Williams, P. H. 2002. Representing biodiversity: Data and procedures for identifying priority areas for conservation. Journal of Biosciences, 27(4), pp. 309-326. doi:10.1007/bf02704962

Pasuljević, G. 1968. Prilog poznavanju herpetofaune Kosova i Metohije. Zbornik filozofskog fakulteta u Prištini, 1, pp. 6174.

Pasuljević, G., \& Džukić, G. 1979. Još jedna populacija šumskog guštera - Lacerta praticola pontica Lantz et Cyren (Reptilia: Lacertidae) na Balkanskom poluostrvu. Biosistematika, 5, pp. 181-186.

Podnar, M., Bruvo, M. B., \& Mayer, W. 2013. Non-concordant phylogeographical patterns of three widely codistributed endemic Western Balkans lacertid lizards (Reptilia, Lacertidae) shaped by specific habitat requirements and different responses to Pleistocene climatic oscillations.
Journal of Zoological Systematics and Evolutionary Research, 52(2), pp. 119-129. doi:10.1111/jzs.12056

Ralev, A., Popović, M., Ružić, M., Shurulinkov, P., Daskalova, D., Spasov, L., \& Crnobrnja-Isailović, J. 2013. new record of Testudo graeca ibera Pallas, 1814, in southern Serbia. Herpetozoa, 25, pp. 151-153.

Sillero, N., Campos, J., Bonardi, A., Corti, C., Creemers, R., Crochet, P.-A., Crnobrnja-Isailović, J., Denoël, M., Ficetola, G. F., Gonçalves, J., Kuzmin, S., Lymberakis, P., de Pous, P., Rodríguez, A., Sindaco, R., Speybroeck, J., Toxopeus, B. Vieites, D. R., \& Vences, M. 2014. Updated distribution and biogeography of amphibians and reptiles of Europe. Amphibia-Reptilia, 35, pp. 1-31.

Sterijovski, B., Tomović, Lj., \& Ajtić, R. 2014. Contribution to the knowledge of the Reptile fauna and diversity in FYR of Macedonia. North-Western Journal of Zoology, 10, pp. 8392.

Tomović, Lj., Ajtić, R., Đoković, Đ., \& Antić, S. 2004. Records of Testudo graeca ibera Pallas, 1814 in Serbia and Montenegro. Herpetozoa, 17, pp. 189-191.

Tomović, Lj., Ajtić, R., Ljubisavljević, K., Urošević, A., Jović, D., Krizmanić, I., Labus, N., Đorđević, S., Kalezić, M.L., Vukov, T., \& Džukić, G. 2014. Reptiles in Serbia: Distribution and diversity patterns. Bulletin of the Natural History Museum, 7, pp. 129-158. doi:10.5937/bnhmb1407129t

Tomović, Lj., Kalezić, M., Džukić, G. (Eds.) 2015a. Gmizavci. In Crvena knjiga faune Srbije.Beograd: Univerzitet u Beogradu - Biološki fakultet / Zavod za zaštitu prirode Srbije. II.

Tomović, Lj., Urošević, A., Ajtić, R., Krizmanić, I., Simović, A., Labus, N., Jović, D., Krstić, M., Đorđević, S., Anđelković, M., Golubović, A., \& Džukić, G. 2015b. Contribution to the knowledge of distribution of Colubrid snakes in Serbia. Ecologica Montenegrina, 2, pp. 162-186.

Uetz, P., Freed, P., Hošek, J. (Eds.) 2017. The Reptile Database. http://www.reptile-database.org. Accessed on 08.01.2018.

Urošević, A., Ljubisavljević, K., Tomović, Lj., Krizmanić, I., Ajtić, R., Simović, A., Labus, N., Jović, D., Golubović, A., Anđelković, M., \& Džukić, G. 2015. Contribution to the knowledge of distribution and diversity of lacertid lizards in Serbia. Ecologica Montenegrina, 2, pp. 197-227. 